Volume 63

Issue 2 Winter 2014: Symposium - A Brave New

World: The Changing Face of Litigation and Law

Article 15

Firm Finance

\title{
Litigation Funding versus Liability Insurance: What's the Difference?
}

Charles Silver

Follow this and additional works at: https://via.library.depaul.edu/law-review

\section{Recommended Citation}

Charles Silver, Litigation Funding versus Liability Insurance: What's the Difference?, 63 DePaul L. Rev. 617 (2014)

Available at: https://via.library.depaul.edu/law-review/vol63/iss2/15

This Article is brought to you for free and open access by the College of Law at Digital Commons@DePaul. It has been accepted for inclusion in DePaul Law Review by an authorized editor of Digital Commons@DePaul. For more information, please contact digitalservices@depaul.edu. 


\title{
LITIGATION FUNDING VERSUS LIABILITY INSURANCE: WHAT'S THE DIFFERENCE?
}

\author{
Charles Silver*
}

\section{INTRODUCTION}

Having studied insurance defense arrangements for years, I was mystified by the strenuous opposition mounted in certain quarters to third-party litigation funding. For it seemed to me that liability insurance, which ordinarily requires insurers to bear both the cost of defending claims and the burden of paying them, was subject to every complaint lodged against third-party funding. Both encourage lawsuits, influence settlement terms, have payers intermeddling in litigation, etc. Yet, in the United States insurers have covered litigation risks for over a century, and no one proposes getting rid of them. To the contrary, some writers, including me, worry that certain actors have too little insurance and should perhaps be required to purchase more. ${ }^{1}$ Yet, if liability insurance and third-party funding are objectionable on the same grounds, why should we want more of one and less of the other?

In this Article, I make good on the claim that the major objections to third-party funding have analogues applicable to liability coverage.

* Roy W. and Eugenia C. McDonald Endowed Chair in Civil Procedure, School of Law, University of Texas at Austin. E-mail: csilver@law.utexas.edu. I am grateful to Ronen Avraham, Michelle DeStefano, Andrew Gold, and Anthony Sebok for comments and suggestions. I sometimes serve as a consultant on litigation matters that may involve issues like those discussed herein.

1. Lynn LoPucki and James J. White famously debated this issue in the context of commercial insurance. See Lynn M. LoPucki, The Death of Liability, 106 Y ALE L.J. 1 (1996); James J. White, Corporate Judgment Proofing: A Response to Lynn LoPucki's The Death of Liability, 107 Y ALE L.J. 1363 (1998); Lynn M. LoPucki, Virtual Judgment Proofing: A Rejoinder, 107 YALE L.J. 1413 (1998). In the context of medical malpractice, my research group documented a sizeable decline in the real amount of professional liability insurance carried by Texas doctors with closed claims, the rarity with which claimants recover more than the policy limits, and a significant shortfall in compensation for plaintiffs who won jury verdicts. See Kathryn Zeiler, Charles Silver, Bernard Black, David A. Hyman \& William M. Sage, Physicians' Insurance Limits and Malpractice Payments: Evidence from Texas Closed Claims, 1990-2003, 36 J. Legal STud. S9 (2007); see also David A. Hyman, Bernard Black, Kathryn Zeiler, Charles Silver \& William M. Sage, Do Defendants Pay What Juries Award? Post-Verdict Haircuts in Texas Medical Malpractice Cases, 1988-2003, 4 J. Empirical Legal Stud. 3 (2007). A plausible implication of this work is that states should enact minimum insurance requirements for health care providers. 
I also explain why the objections have not led us to prohibit carriers from selling insurance, and why third-party funding should survive them as well. When carrying out this project, I focus on contracts between funders and claimants, rather than between funders and lawyers. The former resemble liability insurance arrangements more nearly than the latter, which are substitutes for accumulated wealth, bank loans, and other sources lawyers have traditionally used to finance cases.

I begin by describing the core similarity between liability insurance and third-party litigation funding: the transfer of risks associated with civil litigation. By purchasing insurance, a potential defendant trades a fixed loss in the present for a carrier's willingness to bear an uncertain loss in the future. Third-party litigation funding is the mirror image of this arrangement. A plaintiff accepts a fixed gain today in return for giving a funder a share of a gamble that may or may not pay off. The claim that liability insurance should be permitted while thirdparty funding is barred boils down to the assertion that it should be lawful to trade in potential litigation-related losses but not in potential litigation-related gains. I do not see how this proposition can be maintained. The remaining Parts of this Article address the major objections raised against third-party funding and explore their applicability to liability insurers.

\section{Liability Insurance And Third-Party Funding COMPAREd}

Liability insurance and third-party litigation funding are isomorphs. They evolved independently but have similar structures and functions. ${ }^{2}$ In the United States, liability insurance emerged first. Carriers have been bearing policyholders' tort-related risks since the late $1800 \mathrm{~s},{ }^{3}$ and the expansion of liability coverage in the twentieth century fueled a corresponding and causally dependent growth in the flow of compensation through civil justice systems. ${ }^{4}$

2. Many have observed the similarity between third-party funding and liability insurance. See, e.g., Michele DeStefano, Nonlawyers Influencing Lawyers: Too Many Cooks in the Kitchen or Stone Soup?, 80 Fordham L. Rev. 2791, 2838-40 (2012) (citing sources); Susan Lorde Martin, Leveling the Playing Field, N.Y. Times (Nov. 15, 2010), http://www.nytimes.com/roomfordebate/ 2010/11/15/investing-in-someone-elses-lawsuit/leveling-the-playing-field.

3. See Gary T. Schwartz, The Ethics and the Economics of Tort Liability Insurance, 75 CorNELL L. REv. 313, 314 \& n.6 (1990) (noting that an 1886 employers' liability insurance policy was the first instance of liability insurance in America).

4. The spread of liability coverage and the resulting rise of civil litigation are described in admirable detail in Stephen C. Yeazell, Re-Financing Civil Litigation, 51 DePaul L. Rev. 183 (2001). 
Initially, insurers sold true indemnity policies that required them to reimburse policyholders for losses previously paid. ${ }^{5}$ These original policies did not entitle carriers to defend or settle claims. Over time, working arrangements changed. Insurers started indemnifying policyholders against liability (as contrasted with losses previously paid), and primary insurers assumed control of the defense and settlement of claims. ${ }^{6}$ They became active litigation managers rather than passive indemnitors. They also cut policyholders out of the payment loop. Today, primary liability carriers normally pay claimants directly instead of reimbursing insureds.

Third-party litigation funders-a label applied to businesses that provide financial assistance to persons or companies involved as plaintiffs in civil lawsuits - appeared recently, and their products are still evolving as funders work around legal impediments and fine-tune their business models. ${ }^{7}$ The approach I take as a model involves the transfer of a fractional ownership interest in a claim from a plaintiff to a funder, in return for which the funder pays the plaintiff an agreed amount, which the plaintiff may use to defray litigation costs or, in many instances, as she otherwise desires. Typically, the funder's return is tied to the value added or the level of risk incurred. The amount recovered may proxy for the value a funder's contribution adds. The time needed to obtain a recovery or the level of financial support extended often proxy for the risk a funder incurs.

Liability insurance and third-party funding arrangements also use similar structures to accomplish similar goals. Both increase wealth by using contracts to transfer litigation risks and costs from parties who would rather avoid them to businesses that can bear them more easily. To create risk pools whose results can reliably be predicted, insurers and funders (at least those operating in the consumer sector) diversify

5. See Randall L. Smith \& Fred A. Simpson, Extrinsic Facts \& the Eight Corners Rule Under Texas Law-The World Is Not As Flat As Some Would Have You Believe, 46 S. Tex. L. Rev. 463, 505 (2004) (citing James E. Rhodes, The Liability of Insurance Contract, 4 ME. L. Rev. 65, 67 (1911)).

6. Id. at 506-07.

7. The U.S. Chamber of Commerce is attempting to create insurmountable obstacles for litigation funders by having sympathetic state legislators sponsor bills that would treat funding arrangements as loans subject to consumer finance laws. See 2012 State Legislative Wrap Up, Alliance for Responsible Consumer Legal Funding (July 10, 2012, 2:14 PM), http://blog. arclegalfunding.org/2012/07/10/2012-state-legislative-wrap-up/ (reporting that "[m]embers of the U.S. Chamber of Commerce, the insurance industry and state Chambers of Commerce introduced six pieces of local legislation seeking to ban or severely limit the [consumer legal funding] industry"). For an example of proposed legislation that would cripple the industry under the guise of protecting consumers, see H.B. 1595, 83d Leg., Reg. Sess. (Tex. 2013) (characterizing consumer legal funding as lending and subjecting it to interest rate limitations). 
their exposure across matters that, they hope, are similar but independent. ${ }^{8}$ To create these pools, both insurers and funders must define the risks that are transferred. This is easier for funders than for insurers, who sell many products (car insurance, homeowner's insurance, medical professional liability coverage, etc.), each of which covers a range of liability-producing activities. Insurance policies contain many coverage-defining clauses and exclusions not found in funding contracts, which are limited to specific claims.

Insurers and funders both encounter adverse selection and moralhazard problems and must develop means of handling these difficulties. Adverse selection occurs because parties who are poor risks-for example, bad drivers and plaintiffs with weak claims-are more likely to seek help from insurers and funders than those who are good risks. Parties also possess private information and may misrepresent their riskiness to obtain better terms. ${ }^{9}$ Insurers use the underwriting process to weed out bad risks and policy limits to restrict their exposure to them. Funders use case evaluations, limits on investment size, and plaintiffs' attorneys' willingness to handle claims on contingency to do the same. ${ }^{10}$

Moral-hazard problems arise because the risk transfer reduces the interest a party has in a claim. ${ }^{11}$ A defendant who cares little how a lawsuit turns out (because the carrier must pay the freight) may be unwilling to put much time or effort into the case. Or the defendant,

8. Many litigation funders appear to be too small to operate risk pools that permit the application of the law of large numbers. This may be because the industry is still in its infancy. Alternatively, some funders may operate like specialty insurers that cover nondiversifiable risks. For a discussion, see Steven Garber, Rand Corp., Alternative Litigation Financing in the United States: Issues, Knowns, and UnKnowns 24-26 (2010).

9. See id. at 24.

10. One funder that invests large sums in commercial lawsuits reportedly conducts case evaluations that "averag[e] about 60 to 90 days" in length and cost " $\$ 75,000-\$ 100,000$ for each screening." Id. at 26 (quoting Ralph Lindeman, Third-Party Investors Offer New Funding Source for Major Commercial Lawsuits, Daily ReP. for Executives (BNA), Mar. 5, 2010, at 1, 4); see also Courtney R. Barksdale, Note, All That Glitters Isn't Gold: Analyzing the Costs and Benefits of Litigation Finance, 26 Rev. Litig. 707, 713-14 (2007) ("[L]itigation funding firms review documents from each case to perform an analysis of the merit of claims. Firms request documents such as the client engagement letter, accident reports and medical records from plaintiffs' attorneys to evaluate the claims. In fact, many of these firms employ attorneys to evaluate the claims." (footnotes omitted)).

11. It is helpful to distinguish between two types of moral hazard: primary moral hazard, which affects an insured's incentive to exercise reasonable care before a claim arises; and secondary moral hazard, which affects an insured's incentive to minimize the cost of resolving a claim or, in the case of a funded plaintiff, to maximize a claim's value. Liability insurance generates both types of moral hazard because insureds purchase coverage before claims arise. Third-party funding probably generates only secondary moral hazard, but may conceivably generate primary moral hazard as it becomes more widely available and potential tort victims develop the expectation of purchasing it. 
having been freed from other costs and risks, may focus on secondary effects, such as reputational interests, and may want to minimize them regardless of the impact on the carrier. Insurers use early notice clauses, cooperation requirements, and the threat of withdrawing coverage to motivate defendants.

A funded plaintiff may also be uninterested or may become a risk seeker if only an unusually large recovery will leave any substantial amount for the plaintiff after the contingent fee lawyer and the funder are paid. ${ }^{12}$ Funders motivate plaintiffs by ensuring that they keep some skin in the game, ${ }^{13}$ by staging their financial contributions, and by piggybacking on plaintiffs' relationships with attorneys, who have a fee interest in the recovery and monitor plaintiffs' participation. ${ }^{14}$

Of course, insurers and funders sell their contracts to different parties with different needs. Liability insurers serve potential and actual defendants in civil litigation-usually the former-by acquiring risks associated with losses imposed by law. Third-party funders serve potential and actual plaintiffs - usually the latter-by acquiring risks attached to litigation-related gains. Although both presumably use contracts to maximize the joint welfare of themselves and the parties they work with, the manner in which the contracts operate reflects the opposition of the parties in litigation. ${ }^{15}$ Insurance contracts are designed to minimize expected liability costs, including defense costs and outlays to satisfy claims. Funding contracts are intended to maximize net expected gains from lawsuits.

The tools used to accomplish the respective aims are similar but also differ somewhat. Liability insurers manage quality and cost ruthlessly and creatively. They make defense-related decisions directly, thereby obtaining complete freedom to use their vast experience dealing with lawyers to minimize litigation costs. They decide which lawyers to hire, obtain volume discounts by concentrating work in a small number of firms, maintain staff counsel operations in areas where the volume of work is sufficient to justify the expense, subject lawyers to litigation management guidelines and audits, and use innovative fee

12. Cf. Maya Steinitz, The Litigation Finance Contract, 54 WM. \& MARy L. REv. 455, 489-90 (2012).

13. Sources suggest that funders limit their investments to $20 \%$ of the value of plaintiffs' claims. See, e.g., J. Burton LeBlanc \& S. Anne Saucer, All About Alternative Litigation Financing, Trial, Jan. 2013, at 16, 18 (citing Garber, supra note 8, at 12).

14. Steinitz, supra note 12 , at 505 ("[S]taged financing . . . increases the incentives of the ... plaintiff to expand the effort needed to maintain or enhance the value of the venture or litigation. In other words, it reduces agency problems." (footnote omitted)).

15. On the use of contracts to maximize parties' joint gains, see Alan Schwartz \& Robert E. Scott, Contract Theory and the Limits of Contract Law, 113 Yale L.J. 541 (2003). 
arrangements to motivate outstanding performance. ${ }^{16}$ Insurers also control settlement negotiations and decision making. This enables them to act on their incentive to minimize costs by deploying their knowledge of claim values with maximum effect.

The extent to which third-party funders manage litigation varies across contexts. ${ }^{17}$ Funders who engage in what has been called "consumer legal funding" make small investments in large numbers of cases, with returns tied to the amount advanced and the time that elapses before the funder is paid. ${ }^{18}$ Because these funders typically extend no more than a small fraction of the estimated value of a claim, they have little interest in managing prosecution costs, which are unlikely to affect their returns. They rely on the market for legal services to ensure that plaintiffs are represented by lawyers whose services are reasonably priced and who are incentivized by contingent percentage fees to maximize claim values. Consumer funders also use the market to screen cases. An attorney's willingness to handle a case on contingency signals to a funder that a claim is sufficiently meritorious to warrant an investment. In this respect, funders resemble liability insurers, who also use representation by plaintiffs' attorneys to identify claims that are likely to merit payments.

Not all plaintiffs' attorneys are created equal, of course. Quality differences provide litigation funders the opportunity to discipline the market for legal services by identifying inferior attorneys and avoiding them. Disfavored attorneys will find it hard to compete because they will have difficulty attracting clients and experience higher operating costs. At this time, however, the extent to which funders distinguish among attorneys is not clear.

In theory, funders operating in the commercial litigation sector, where investments often exceed $\$ 1$ million, could become more extensively involved in the conduct of litigation and would more closely

16. See William T. Barker \& Charles Silver, Professional Responsibilities of Insurance Defense Counsel $\$ 1.02$ (2012); see also Charles Silver, Flat Fees and Staff Attorneys: Unnecessary Casualties in the Continuing Battle over the Law Governing Insurance Defense Lawyers, 4 Conn. Ins. L.J. 205, 216-18 (1997). Insurance scholars once hoped that large insurers would also manage the cost and quality of legal services for claimants. See Werner Pfennigstorf \& Spencer L. Kimball, Regulation of Legal Service Plans, 1977 Am. B. Found. Res. J. 357, 411-13. The market did not develop, however.

17. The extent of funder control varies considerably across countries and is more limited in the United States than elsewhere. For an extensive account, see Jasminka Kalajdzic et al., Justice for Profit: A Comparative Analysis of Australian, Canadian and U.S. Third Party Litigation Funding, 61 Ам. J. СомP. L. 93 (2013). Funding arrangements in many countries are described in The Costs and Funding of Civil Litigation: A Comparative Perspective (Christopher Hodges et al. eds., 2010).

18. GARBer, supra note 8 , at 9,12 . 
resemble liability insurers if they did. They could demand the right to select counsel, decide litigation strategy, and consider settlement opportunities. In fact, the extent of their involvement varies greatly. There are famous instances of "intermeddling," in which funders controlled the inception and conduct of litigation, but there are also examples in which they took "back seat" positions despite making large investments. ${ }^{19}$ Both the history of liability insurance and microeconomic theory suggest that extensive involvement by commercial litigation funders may become the norm. ${ }^{20}$

Funders, who tend to be experienced lawyers with strong backgrounds in litigation, may also enhance the quality of legal services by monitoring plaintiffs' attorneys. They may often be able to assess the caliber of the representation plaintiffs receive more accurately than plaintiffs can themselves, and they may also provide more informed feedback on litigation strategy and other matters to lawyers. In effect, they have the potential to become agents who watch other agents for the benefit of themselves and the plaintiffs in whose cases they invest. ${ }^{21}$ One can easily imagine them improving their monitoring abilities by requiring plaintiffs' lawyers to adhere to litigation management guidelines and subjecting them to expense audits. Insurers subject defense lawyers to these management techniques already.

\section{Liability Insurance AND Third-PARty Funding CONTRASTED}

In the preceding Part, I attempted to set up an inference that one can shed light on the merits of objections to third-party litigation funding by studying the law governing the defense and settlement of claims by liability insurers. In my view, the two methods of handling lawsuit-related risks have a good deal in common, especially certain problems of microeconomics.

Insurance and litigation funding are not identical, however, and the differences between them could make it perilous to reason from one to the other. This is Michelle Boardman's view. In an article entitled Insurers Defend and Third Parties Fund, she argues that the analogy I

19. See ABA Comm'n on Ethics 20/20, Informational Report to the House of DeleGAtes 23 \& n. 82 (2012) [hereinafter ABA White PAPER] (reporting instances in which "[alternative litigation funding] suppliers disclaim[ed] any control over the decision-making of lawyers, stating that they are in an entirely passive role").

20. See Steinitz, supra note 12, at 501-17 (contending that funders should exercise extensive control over the conduct of litigation).

21. Elizabeth Chamblee Burch, Financiers as Monitors in Aggregate Litigation, 87 N.Y.U. L. Rev. 1273, 1315 (2012); see also Steinitz, supra note 12, at 499-500. 
draw is strained. ${ }^{22}$ In her view, the differences between liability insurance and third-party funding overwhelm "the occasional similarity." Consequently, she contends, liability insurance has little to teach about the merits of litigation funding.

Boardman identifies five "key" differences between liability insurance and lawsuit funding:

(1) the contractual relationship [between the policyholder and the liability carrier] precedes the litigation.

Thus,

(2) the insurer's involvement in the litigation is automatic, not an investment choice, and

(3) litigation funding is not the primary purpose of the contract.

Once a legal claim is made,

(4) the policyholder has a duty to cooperate with the insurer, and

(5) the policyholder and the insurer are co-clients of the [defense] lawyer. ${ }^{23}$

In her view, these differences undermine the following three common arguments for litigation funding:

First, insurers are third-party litigation funders (as are contingency fee lawyers). Thus, we can see that third-party litigation funding works well in the United States already and should not cause alarm. Second, litigation funding is necessary on the plaintiff side to restore parity between plaintiffs and insurer-backed defendants. Supporters have not used this language, but one version of the claim is that insurer defense creates an imbalance with negative externalities. Third, insurer control of policyholder litigation is less intrusive than funder involvement will be. Because insurer control is accepted, a lower level of funder involvement should be as well. ${ }^{24}$

In sum, Boardman contends, liability carrier involvement on the defense side of lawsuits cannot legitimate the participation of funders on the plaintiff side. ${ }^{25}$

It is, of course, well and good to remind readers of the limits of analogical reasoning. But it is also reasonable to ask people who support one practice while opposing another to offer compelling distinctions. In my view, the similarities between liability insurance and litigation funding are stronger than the differences Boardman points out.

Consider the "key" differences between liability insurance and litigation funding that Boardman identifies. Not all forms of liability in-

22. Michelle Boardman, Insurers Defend and Third Parties Fund: A Comparison of Litigation Participation, 8 J.L. ECON. \& PoL'Y 673 (2012).

23. Id. at 680 (emphasis added) (footnotes omitted).

24. Id. at $689-90$.

25. Id. at 673 . 
surance share them. First and foremost, not all liability insurance policies are sold before losses occur. Consequently, not all liability insurers can be said to become involved in lawsuits automatically rather than by choice. ${ }^{26}$

Boardman seems not to know that defendants already caught up in litigation can buy retroactive coverage for existing liability claims. ${ }^{27} \mathrm{~A}$ famous example involved the MGM Grand Hotel, which caught fire on November 21, 1980.

After the fire, MGM . . . obtained an additional $\$ 170$ million in coverage as retroactive insurance. This was accomplished well after the fire had occurred, the physical damage had been assessed, and numerous suits had been filed against MGM. When coverage began, however, the loss was unknown, and insurance was obtainable because the extent of MGM's legal liability had not yet been determined. ${ }^{28}$

Retroactive coverage, also known as "loss mitigation" insurance, is available for lawsuits creating securities, employment, intellectual property, and product liability exposures. ${ }^{29}$

Retroactive policies lack at least two of Boardman's "key" features. They relate to events and lawsuits that precede the contractual relationship between the policyholder and the carrier, and they are sold by carriers that decide to incur exposure to lawsuits that are already ongoing or highly likely to occur. Retroactive coverage may also possess a third feature that is at odds with Boardman's account. If the

26. See Kent D. Syverud, On the Demand for Liability Insurance, 72 Tex. L. Rev. 1629, 1644-46 (1994).

27. For discussions of retroactive insurance and the underlying economics, see Stephen P. Baginski et al., Catastrophic Events and Retroactive Liability Insurance: The Case of the MGM Grand Fire, 58 J. Risk \& Ins. 247 (1991); Michael L. Smith \& Robert C. Witt, An Economic Analysis of Retroactive Liability Insurance, 52 J. Risk \& Ins. 379 (1985); Emilio C. Venezian \& Joseph A. Fields, Informational Asymmetries in Retroactive Insurance, 54 J. Risk \& INs. 780 (1987).

28. Matt W. Holley, The "Fortuity Doctrine": Misapplying the Known Loss Rule to Liability Insurance Policies, 41 Tex. TeCH L. Rev. 529, 533 (2009) (footnotes omitted).

29. Susanne Sclafane, Cover Available for Known Securities Claims, Nat'l Underwriter: Prop. \& Casualty/Risk \& Benefits Mgmt. Edition, Jan. 31, 2000, at 6, 6, available at http:// m.propertycasualty360.com/2000/02/05/cover-available-for-known-securities-claims. Another type of retroactive policy is simply a loan by the insurer to cover known losses, which the policyholder repays over time in the form of premiums. See Kali N. Bracey et al., Client Advisory: When the Regulators Come Calling, Will Your Company Have the Right D\&O Coverage?, JenNER \& BLOCK (Feb. 2, 2010), http://jenner.com/system/assets/publications/541/original/When The_Regulators_Come_Calling_Will_Your_Company_Have_The_Right_DO_Coverage_02.10. pdf?1313681432. ("Loss mitigation products often involve a retroactive insurance policy in which an insurer lends a policyholder money to pay for known losses in the first year of the policy and the 'premiums' the policyholder pays in subsequent policy years are actually repayments on the loan."). The similarity between this form of insurance and litigation funding could hardly be clearer. 
insurer agrees to bear defense costs, litigation funding will be a primary purpose of the contract. ${ }^{30}$ Because liability insurance need not conform to many of Boardman's "key" features, it seems odd to assign those features critical importance when comparing liability insurance and third-party litigation funding.

Now consider Boardman's caution against using the presence of insurers on the defense side to justify the participation of third-party funders for plaintiffs:

[T] he problem with the claim that insurers are litigation financiers is not its inaccuracy but its superficiality. Insurers obviously pay for legal costs in litigation. In the vast majority of cases, insurers do this ... as co-clients of the lawyer representing the defendant .... In other words, the insurer is ... not a third party .... The difference between these relationships and third-party litigation funding does not mean that the two should never be mentioned in the same breath. It does mean that in an analysis of third-party litigation funding, little can be said to automatically follow from the fact that insurers fund litigation. ${ }^{31}$

Here, Boardman makes a basic mistake. The fact, when it is one, ${ }^{32}$ that an insurer is a co-client of the defense lawyer handling the liability suit against the policyholder does not make the insurer a first-party funder. ${ }^{33}$ The carrier remains a third party to the litigation because it is not a named defendant. It is a nonparty using particular control and funding arrangements to minimize its contractual exposure to losses.

30. An example of a retroactive D\&O policy that covered defense costs appears in Sclafane, supra note 29.

31. Boardman, supra note 22, at 691.

32. Not all forms of liability insurance give insurers control of lawsuits against policyholders. Some leave policyholders in charge. Insurance covering securities fraud claims against the directors and officers of public companies ("D\&O" insurance) is an example. See Tom Baker \& Rick Swedloff, Regulation by Liability Insurance: From Auto to Lawyers Professional Liability, 60 UCLA L. Rev. 1412, 1426 (2013) (explaining that "D\&O insurance policies are 'defense cost payment' policies, rather than 'duty to defend' policies, so that someone insured by a D\&O policy gets to choose their own defense lawyer and direct their own defense"). Some professional liability policies for attorneys also leave lawyers in charge. See LawPRO, 2013 ProfesSIONAL LIABILITy INSURANCE FOR LAWYERs 2 (2013), available at http://www.lawpro.ca/ insurance/pdf/LAWPRO_Policy2013.pdf (giving carrier a duty to defend but not a right to defend). Insurers that lack the right to control the defense normally are third-party payers, not coclients of the lawyers who defend their insureds.

33. Kent Syverud and I provided a systematic defense of the view that insurers are co-clients. See Charles Silver \& Kent D. Syverud, The Professional Responsibilities of Insurance Defense Lawyers, 45 Duke L.J. 255 (1995); see also Charles Silver, Does Insurance Defense Counsel Represent the Company or the Insured?, 72 Tex. L. Rev. 1583 (1994), cited in Boardman, supra note 22 , at 687 n.55. But we explicitly left open the possibility that a carrier can be a non-client. Silver \& Syverud, supra, at 274. Some states also deny insurers client status as a matter of law. See BARKer \& Silver, supra note $16, \S 4.04$. The doctrine is indefensible, but it is the law. Consequently, in several states, carriers are not co-clients. 
Even if Boardman were right to deny that insurers are third parties, litigation funders could eliminate the difference by mimicking insurers and becoming co-clients too. Nothing prevents a funder, a plaintiff, and a contingent fee lawyer from agreeing that the funder will be a coclient. They have the same freedom as insurers, policyholders, and defense lawyers to structure their relationships as they wish. They can even duplicate the arrangements policyholders and insurers use to their advantage by giving funders control of defense and settlement decisions.

Working arrangements between plaintiffs and funders may eventually resemble those used by insurers and policyholders more closely than they do today. If there is an advantage to be gained, they probably will; otherwise, they will not. Either way, it is odd to think, as Boardman apparently does, that the details of working arrangements should distract one from the bigger picture. Insurers and funders both use contracts to acquire exposures to lawsuits that they underwrite.

Now consider Boardman's third contention: that funder involvement in litigation may be more objectionable than insurer involvement, even though the latter is more extensive. Boardman mentions many considerations when making this point, ${ }^{34}$ the most important of which seems to be that liability carriers have more skin in the game. "[I]t is not simply that insurers have more control over their policyholder's [sic] defense; insurers have more at stake in the litigation and play a more equal role as co-client." 35 Whereas insurers normally pay

34. Boardman appears to misunderstand some legal doctrines applicable to insurance defense and settlement arrangements. She writes that "both the insurance contract and the common law charge the policyholder and the insurer with cooperation and fiduciary duties toward one another." Boardman, supra note 22, at 696 . In fact, when it comes to the defense and settlement of claims, insurers are not policyholders' fiduciaries. Insurers may, and commonly do, give their own interests weight. See, e.g., In re Allstate Ins. Co., 722 S.W.2d 947, 952 (Mo. 1987) ("[A defending liability insurer] may make economic decisions without the assent of the insured. The insured may want a quick settlement to eliminate further demands on time and energy, but the insurer does not have to settle unless a satisfactory offer is forthcoming. Or the insurer may accept a settlement offer even though the insured wants to go to trial to establish freedom from fault. The insurer may decide what to spend in defense, what discovery is to be had, and what experts to hire. It also has the right to select counsel to defend its interests." (footnote omitted)); Douglas R. Richmond, Trust Me: Insurers Are Not Fiduciaries to Their Insureds, $88 \mathrm{Ky}$. L.J. 1 (2000). Because Boardman gets the doctrine wrong, she also mistakenly thinks she can weaken the analogy between litigation funding and insurance defense by pointing out that a funder "will be tempted to privilege its interests over the plaintiff's when they diverge." Boardman, supra note 22 , at 696 . Rather, this observation strengthens the analogy. Most controversies concerning the professional responsibilities of insurance defense lawyers involve conflict situations in which insurers may put their own interests ahead of the interests of their insureds.

35. Boardman, supra note 22, at 695. 
all litigation and settlement costs, ${ }^{36}$ funders bear only a fraction of the former and receive only part of the latter. Consequently, insurer involvement in litigation is more easily justified than funder involvement and raises fewer interest conflicts.

It is hard to know what to make of this claim. On the one hand, Boardman rightly asserts that insurers and funders have different stakes in the lawsuits in which they participate. This is inevitable. Carriers bear losses while funders share in gains. Their positions differ from the get-go. The law also permits insurers to cover losses in their entirety. Funders cannot as easily acquire complete ownership of claims. If Boardman's point is that, because of these differences, conflicts will differ in frequency, severity, and nature across the two contexts, she is surely correct.

That admitted, the deeper similarities again outweigh the differences. First, conflicts arise in both insured representations and funded representations because in both it is impossible to use contractual arrangements that achieve first-best results. First-best contracts would incentivize parties to maximize joint gains in all contexts. Real insurance contracts and funding contracts fail this test because, under both, situations may arise in which individual contracting parties can advance their own self-interest by acting other than for the common good of all contracting parties considered together.

Both insurance relationships and funding relationships involve a trio of parties: insurers, policyholders, and defense lawyers on the one hand; funders, plaintiffs, and plaintiffs' attorneys on the other. Ideally, the contracts governing these tripartite relationships-the insurance contract and retainer agreement on one side and the funding contract and retainer agreement on the other-would maximize the joint gains of all three participants by incentivizing each participant always to act for the benefit of all.

But, as we know, each participant can sometimes gain by acting to the disadvantage of the group. In the insurance defense context, insurers may find it advantageous to reject policy-limits settlement demands that, if accepted, would minimize joint losses. Policyholders worried about reputational interests or excess exposure may benefit by pressuring insurers to accept within-limits settlement demands that

36. My empirical research group has produced the best evidence for this claim. See Charles Silver et al., Malpractice Payouts and Malpractice Insurance: Evidence from Texas Closed Claims, 1990-2003, 33 Geneva Papers on Risk \& Ins.: Issues \& Prac. 177, 182-84 (2008); see also Zeiler et al., supra note 1, at S23-26. The tendency of claims to settle at or within the policy limits being admitted, it is also true that many policyholders are underinsured relative to possible judgments. An unknown number of these policyholders (probably many) lack attachable assets. 
are unreasonably high. Defense lawyers may advise insurers to reject reasonable demands because they charge by the hour and prefer to keep working.

Analogous conflicts arise on the plaintiffs' side. A funder may prefer a cheap, early settlement to a later, wealth-maximizing one because its portion of a lawsuit's upside potential is small. A plaintiff may reject a reasonable settlement offer and take a flyer at trial because only a victory at trial can produce a substantial benefit for the plaintiff. A lawyer working on contingency may reduce his or her own exposure to risk by spreading time across a portfolio of cases in a way that maximizes the expected value of none.

Because the contracts that govern the two tripartite relationships fail to eliminate conflicts like these, they are "constrained efficient," not "first-best." 37 They reduce the frequency and severity of conflicts to efficient levels, given the informational and other constraints the three participants face. This is as it should be. Conflicts are sources of costs, so the participants should want to minimize them and should settle on structures that have this effect. For example, in insured tripartite relationships, the combination of complete insurer ownership of losses, plenary insurer control of the defense, insurer financial responsibility for the defense, and insurer discretion to settle works well. ${ }^{38}$ In funded tripartite relationships, constrained efficient working arrangements are still evolving. Partial funder ownership of gains paired with the usual relationship between the contingent fee lawyer and the plaintiff seems to work well in some contexts. In others, funders desire more control because they make larger commitments and face bigger risks. Regardless, the similarity of the conflict problems in the two tripartite relationships is clear.

This is why lessons learned in one context may generate helpful insights into the other. Sometimes liability insurers are defense lawyers' co-clients; sometimes they are defense lawyers' third-party payers. ${ }^{39}$ Doctrines have evolved to govern lawyers' professional responsibilities in both situations. These doctrines may be valuable sources of

37. The term "constrained efficient" is borrowed from Schwartz \& Scott, supra note 15, at 554 n.24.

38. In many contexts, primary insurers bear less than $100 \%$ of policyholders' exposure. This is true in commercial contexts, where primary insurers often share coverage with excess insurers, whose policies kick in when the primary layer is exhausted. It is also true when policyholders have deductibles or attachable assets that could be seized in the event of an uninsured judgment in excess of the primary limits.

39. See BARKer \& Silver, supra note 16, §§ 4.01, 4.07 (discussing insurers' status); see also James M. Fischer, Insurer-Policyholder Interests, Defense Counsel's Professional Duties, and the Allocation of Power to Control the Defense, 14 Conn. Ins. L.J. 21, 40 (2007). 
guidance for plaintiffs' attorneys in funded cases. When funders are co-clients, as they may be but rarely are, plaintiffs' attorneys may take guidance from the law governing co-client relationships, which regulates, among other things, whether confidential information may be shared. When funders are third-party payers, lawyers may look to the law governing relationships with third parties instead. Because the common law takes note of the structural features of representations, it has informational value outside the specific cases through which it evolves.

I turn lastly to Boardman's second claim, which criticizes the assertion that litigation funding for plaintiffs will give them parity with defendants, who are funded by insurers. ${ }^{40}$ Again, when making this point, Boardman mentions a host of considerations. But she seems to be concerned mainly with the wisdom of allowing plaintiffs to offset an advantage defendants gain by purchasing insurance: risk-neutral decision making. Because defendants are risk-averse to start with, Boardman contends, they will predictably pay too much to avoid litigation. ${ }^{41}$ This gives plaintiffs an unmerited advantage in settlement negotiations. Insurance offsets this advantage by giving carriers control of decisions. Being risk-neutral, carriers will only pay in settlement the expected value of claims at trial.

The logical next step would be for Boardman to argue that the corrective will be undone if plaintiffs are allowed to transfer risk to lawsuit funders. Oddly, she does not say this. Nor does she say anything else that might lead one to conclude that outside funding will skew settlement values in plaintiffs' favor illegitimately. Instead, she appears to praise litigation funding as a means of ensuring accurate settlements that reflect real claim values rather than plaintiffs' personal finances or their attitudes toward risk:

Having taken this advantage [i.e., the defendant's aversion to risk] away from the plaintiff through insurance defense, should we restore parity (if that is what it does) by allowing the plaintiff to transfer his litigation risk? For individual plaintiffs, the question is what

\footnotetext{
40. Boardman, supra note 22 , at $692-94$.

41. It would be an error to say that business corporations, insured or not, are risk-averse. Being artificial persons rather than natural ones, corporations cannot have attitudes toward risk. See J.B. Heaton, Settlement Pressure, 25 Int'L Rev. L. \& Econ. 264, 272 (2005) (“[R]isk aversion is a theoretical concept appropriate for individuals."). The most one can say is that corporations sometimes act (through the human beings who run them) as if they were risk-averse. I assume that this is what Professor Boardman meant to convey, and it is certainly what I mean to say when I write of risk-averse behavior by corporate entities. The frequency of "as if risk-averse" conduct by corporations involved in civil litigation is an empirical question concerning which little evidence has been offered. For a discussion, see Charles Silver, "We're Scared to Death": Class Certification and Blackmail, 78 N.Y.U. L. Rev. 1357, 1408-15 (2003).
} 
value litigation funding will add over contingency fee arrangements; lawsuit lending will give some plaintiffs the resources and time necessary to continue a suit he would otherwise be forced to settle "early." For commercial plaintiffs, the question of parity also comes down to efficient settlement.[42] Litigation funding may increase the accuracy of settlements so that they are based on the parties' expectations about the value of the suit and not a reflection of one party's risk preferences. This is the strongest point that emerges from the comparisons between insurer defense and litigation funding. ${ }^{43}$

As I read this passage, Boardman draws an analogy between litigation funding and insurance. Just as liability coverage brings risk-neutrality to the defense side, third-party funding brings risk-neutrality to plaintiffs. The result should be accurate settlements that reflect the expected value of claims, as she indicates. Boardman's second objection does not really seem to be one.

To the contrary, if litigation funding enables plaintiffs to hold out for larger payments, whether by ameliorating their short-term financial needs or by transferring control to risk-neutral decision makers, the results should be to the good. ${ }^{44}$ The single, most robust finding produced by empirical studies of tort litigation is that victims are undercompensated for their losses. ${ }^{45}$ Many injured victims simply "lump it." They neither sue nor take other steps to obtain compensation. Those who do sue often learn that the tort system is stingy. On average, victims do not recover even their hard costs-their out-of-pocket expenses and lost wages-let alone recompense for their pain and suffering, diminished enjoyment of life, or other soft damages. Juries also frequently send plaintiffs with valid claims home empty-handed, perhaps because defendants outspend plaintiffs in cases that are tried. The empirically based argument for leveling the playing field is pretty good.

\section{Maintenance, Champerty, And Barratry}

Historically, certain common law doctrines and statutes forbade third parties, including lawyers, from supporting lawsuits financially. These offenses, known as maintenance, champerty, and barratry, were

42. Again, it is a mistake to attribute attitudes toward risk to corporations. See supra note 41.

43. Boardman, supra note 22, at 693 (emphasis added) (footnote omitted).

44. It is widely accepted that medical malpractice plaintiffs tend to be risk-averse. See Henry S. Farber \& Michelle J. White, Medical Malpractice: An Empirical Examination of the Litigation Process, 22 RAND J. Econ. 199, 208 (1991); see also Stephen J. Spurr \& Walter O. Simmons, Medical Malpractice in Michigan: An Economic Analysis, 21 J. Health Pol. Pol'y \& L. 315, 316 (1996).

45. See Deborah L. Rhode, Frivolous Litigation and Civil Justice Reform: Miscasting the Problem, Recasting the Solution, 54 Duke L.J. 447, 459-60 \& nn.91-95 (2004). 
related: "[P]ut simply, maintenance is helping another prosecute a suit; champerty is maintaining a suit in return for a financial interest in the outcome; and barratry is a continuing practice of maintenance or champerty." 46 In the United States, the existence and details of these prohibitions vary both over time and from place to place, but today none of them prevents contingent fee lawyers from helping clients by bearing litigation costs, subject to the constraint that the client must reimburse the lawyer for the advances from any recovery. Some states, including Texas oddly enough, even allow lawyers to help clients with personal living expenses. ${ }^{47}$ Nonlawyers still remain subject to the prohibitions, however, in states that continue to impose them. ${ }^{48}$

The policy reasons offered in support of prohibitions on maintenance, champerty, and barratry resemble those offered in justification of other restrictions on lawsuits, generally known as tort reforms. Allegedly, third-party funding promotes frivolous litigation, vindictive litigation ("meritorious litigation motivated by an improper motive"), and intermeddling by nonparties in the conduct of the litigation, such as by "determining trial strategy or controlling settlement." 49

The extent to which litigation funding by lawyers or third parties has unwanted effects is an empirical matter, and the supporting evidence is weak. For example, except in the area of securities fraud class action litigation, no study finds that contingent fee lawyers frequently file frivolous suits. To the contrary, many report that these lawyers are selective, rejecting requests for representation when claims are weak on the merits or involve damages too small to warrant the costs and risks of litigation. ${ }^{50}$ Third-party funders should also invest conservatively. Those operating in the commercial sector make sizeable investments in a small number of cases. Facing large, undiversified risks, they should choose cases with care. Even in the consumer area, where funders invest small sums in lots of cases, they have difficulty building portfolios large enough to yield predictable results.

46. ABA White PAPer, supra note 19, at 9 (alteration in original) (quoting Osprey, Inc. v. Cabana Ltd. P'ship, 532 S.E.2d 269, 273 (S.C. 2000)) (internal quotation marks omitted).

47. See Tex. Disciplinary Rules of Prof'l Conduct R. 1.08(d)(1) (2012). I say "oddly enough" because Texas is a notoriously anti-litigation state.

48. See DeStefano, supra note 2, at 2796. DeStefano contends that lawyers might serve clients better if ethics rules permitted them to work and interact more freely with third-party funders who are not lawyers, at least in commercial lawsuits.

49. ABA White Paper, supra note 19, at 11.

50. On the selectivity of plaintiffs' attorneys and their reasons for declining cases, see LaRae I. Huycke \& Mark M. Huycke, Characteristics of Potential Plaintiffs in Malpractice Litigation, 120 Annals Internal Med. 792, 796 (1994); Herbert M. Kritzer, Contingency Fee Lawyers As Gatekeepers in the Civil Justice System, 81 Judicature 22, 24 (1997); Herbert M. Kritzer, Holding Back the Floodtide: The Role of Contingent Fee Lawyers, Wis. Law., Mar. 1997, at 10, 63. 
Consumer litigation funders should therefore also seek out strong cases.

Turning finally to the matter of controlling lawsuits to which one is not a party, the charge is probably true with regard to contingent fee lawyers but neither wholly true nor wholly false when applied to thirdparty funders. Starting with lawyers, it is well known that clients look to attorneys for guidance and normally follow their lead. In this respect, clients resemble patients and other laypersons who participate in relationships with doctors and other sophisticated service providers. In each instance, the recipient desires the provider's advice and, assuming proper conduct by the provider, is better off having it. Contingent fee lawyers' recommendations should be especially reliable because their financial interests are aligned with their clients'. A policy intended to prevent clients from relying on lawyers' advice would be revolutionary and unjustifiable. Advice is one of the essential services clients hire lawyers to provide.

Turning now to third-party litigation funders, they sometimes seek to influence or control the conduct of lawsuits, and the degree to which they do so varies. ${ }^{51}$ In small personal injury cases, where they typically have only a few thousand dollars at risk, they are often passive investors. When their investments are larger, as is often true in commercial lawsuits, funders

may seek to exercise some measure of control over the litigation, including the identity of lawyers pursing the claims, litigation strategy to be employed, and whether to accept a settlement offer or refuse it and continue to trial. . . .

... In one Florida case, for example, the supplier had the right "to approve the filing of the lawsuit; controlled the selection of the plaintiffs' attorneys; recruited fact and expert witnesses; received, reviewed and approved counsel's bills; and had the ability to veto any settlement agreements." 52

The extent of funder control of litigation is thus a factual matter about which it is difficult to generalize. The charge of interfering in lawsuits to which they are not parties obviously rings truer when funders demand extensive control than when they do not. ${ }^{53}$

Putting the truth of the allegations to one side, cannot the same charges be leveled against liability insurers? Might not third-party litigation funding on the defense side encourage frivolous lawsuits, vin-

51. ABA White PAPer, supra note 19, at 21-22 (discussing variations in degree of funder control).

52. Id. at 22 (quoting Abu-Ghazaleh v. Chaul, 36 So. 3d 691, 693 (Fla. Dist. Ct. App. 2009)).

53. For an argument that third-party funders should be treated as real parties in interest and should control litigation of funded claims, see Steinitz, supra note 12. 
dictive lawsuits, and intermeddling in the conduct of litigation ${ }^{54}$ Affirmative answers seem clear.

To see why, one must first understand that insurance makes many potential defendants more attractive targets for lawsuits than they would otherwise be. This is especially true in the personal lines area, where most policyholders have too few attachable assets to be worth suing. As Stephen Yeazell observed in a wonderful article explaining the link between liability coverage and the growth of civil litigation, "No one working on a contingent fee intentionally sues an insolvent defendant." ${ }_{55}$ The reason for filing a damages action is almost always to get paid. Because liability insurance makes money available to satisfy covered claims, it encourages litigation, including lawsuits that some might describe as vexatious or meritless.

Tort reform advocates, who oppose third-party funding for plaintiffs vehemently, are in no position to deny that liability insurance for defendants has this effect. They complain loudly that most lawsuits against doctors are meritless. Because liability insurers fund essentially $100 \%$ of the payments in medical malpractice cases, liability insurance must be the magnet that attracts frivolous medical malpractice claims. ${ }^{56}$ The same must be true in other areas, such as securities fraud litigation against the directors and officers of public companies, where liability insurers are the bankers for the civil justice system and nonmeritorious cases are said to abound.

Liability carriers also meddle in the conduct of litigation routinely. Standard policies sold in diverse coverage lines give them plenary control of the defense and settlement of claims. When exercising their contractual rights, they may consider their own interests and do what they think best, even when policyholders disagree. These arrangements make sense because insurers bear all but a small fraction of the cost of defending and settling liability claims. ${ }^{57}$ Even so, because they are third parties, not defendants in litigation, liability carriers are intermeddlers nonpareil.

Given the ease of connecting liability insurance to the frequency of lawsuits of all quality types and the extent of carrier control, the maintenance-, champerty-, and barratry-based objections to third-party funding seem to merit little weight. Because the policy concerns that

54. It may seem more natural to suggest that the presence of insurance increases the likelihood of frivolous or vexatious conduct in connection with the defense of litigation.

55. Yeazell, supra note 4, at 186.

56. See supra note 36 and accompanying text.

57. Zeiler et al., supra note 36 , at S11, found that insurers bore $99.4 \%$ of payments on medical malpractice claims that closed in Texas 1988-2003. 
underlie these prohibitions have not been invoked to forbid defendants from enjoying the benefits of liability insurance, there is no obvious reason to deny plaintiffs the similar benefits third-party funders provide. The fact that liability insurance is mandatory in many contexts may strengthen this conclusion. ${ }^{58}$ To the extent that these requirements reflect the desire to ensure that sufficient assets are available to cover tort-related losses, they establish that victims' interests often trump concerns about encouraging lawsuits or third-party intermeddling.

Finally, it bears mention that insurers often fund the prosecution of civil lawsuits after satisfying claims and becoming subrogated to the rights of insureds. ${ }^{59}$ For example, after paying for repairs to a policyholder's damaged car, an automobile insurer may underwrite a lawsuit against the driver thought to have caused the accident, or a homeowner's carrier may sue a plumbing contractor whose shoddy work caused a policyholder's kitchen to flood. The policyholder will likely be the nominal plaintiff in the lawsuit and may also have a financial stake in it, such as an uninsured loss or a deductible. ${ }^{60}$ But the carrier may fund the subrogation action, control it, and be the real party in interest for much of the case, having stepped into the policyholder's shoes by acquiring its right to sue. Although third-party funding of lawsuits has spawned considerable controversy, there is no equivalent debate over the propriety of insurer-financed subrogation lawsuits. This is true even though subrogation involves claim transfers and often claim-sharing, and clearly increases the resources that are available to support litigation.

58. States require drivers to maintain minimum levels of liability coverage as a condition for obtaining licenses or renewing vehicle registrations. Homeowner's insurance, which contains a liability component, is a practical condition for obtaining a mortgage. Many hospitals and provider organizations require doctors to purchase medical malpractice insurance.

59. See William E. Gericke, Remember the Basics_Make Sure the Insured Knows Whether Subrogation Counsel Is Representing Their Interests, Subrogation \& Recovery L. Blog (Feb. 20, 2012, 12:03 PM), http://www.subrogationrecoverylawblog.com/2012/02/articles/subroroundup/remember-the-basicsmake-sure-the-insured-knows-whether-subrogation-counsel-isrepresenting-their-interests/.

60. When a policyholder has a stake in a subrogation action, settlement-related conflicts can arise like those that sometimes occur between plaintiffs and funders. For a discussion of conflicts in subrogation cases, see Anthony J. Sebok, Control Issues: Litigation Investment, Insurance Law, and Double Standards (Benjamin N. Cardozo Sch. of Law Jacob Burns Inst. for Advanced Legal Studies, Faculty Research Paper No. 394, 2013), available at http://ssrn.com/abstract= 2271762. 


\section{The Requirement that Attorneys Exercise Independent Professional Judgment}

Many sources express the concern that third-party funding may prevent lawyers from giving clients the benefit of their independent professional judgment, something all states' disciplinary rules require. ${ }^{61}$ The ABA's Working Group on Alternative Litigation Finance (Working Group) expressed this view. It argued that a contract "delegating decision-making authority" to a third-party funder

may create such a limitation on an attorney's professional judgment that a reasonable lawyer might conclude that it is impossible to provide competent representation to that client. . . . For example, a provision in a contract may permit the supplier to refuse further funding if the lawyer makes decisions in the course of the representation with which the supplier has a fundamental disagreement. The lawyer, on the other hand, has an obligation to act with reasonable competence and diligence in the representation of the client, and may reasonably believe that the funder's second-guessing of decisions made in the representation of the client is an unreasonable interference with the lawyer's professional judgment. ${ }^{62}$

The identical objection was raised against liability insurers' use of litigation management guidelines. Guidelines, we were told, interfered with defense lawyers' independent professional judgment because they restricted the means lawyers could use to deliver legal services to policyholders. Lawyers had to be free to decide how much legal research would be done, whether lawyers or paralegals would handle particular tasks, whether to take discovery, whether to file motions and pleadings, etc. ${ }^{63}$

Although advisory committees and courts in some states agreed with this charge, most rejected it and rightly so. ${ }^{64}$ First, as a linguistic matter, it is obvious that a rule requiring lawyers to "exercise indepen-

61. See, e.g., U.S. Chamber Inst. for Legal Reform, Third Party Financing: Ethical \& Legal Ramifications in Collective Actions 16 (2009) (contending that "[a]ttorneys advising a client at the outset of a case may be reluctant to provide the client full and candid advice in writing, knowing that any communications could be viewed by the funder as part of its diligence, and then would be available to the opposing party in discovery").

62. ABA White PAPer, supra note 19, at 23. The duty to exercise independent professional judgment is memorialized in Rules 1.8, 2.1, and 5.4 of the Model Rules of Professional Conduct. See id. at $4 \&$ nn.7-8.

63. See, e.g., Supreme Court of Ohio Bd. of Comm'rs on Grievances and Discipline, Op. 20003 (2000) (holding that litigation management guidelines interfere with defense lawyers' independent professional judgment in the ways identified in the text).

64. The controversy surrounding litigation management guidelines and my views on the professional responsibility issues they raise are set out in Charles Silver, When Should Government Regulate Lawyer-Client Relationships? The Campaign to Prevent Insurers from Managing Defense Costs, 44 ARIz. L. REv. 787 (2002), which also contains a list of relevant advisory ethics opinions. See id. at app. 1; see also BARKer \& Silver, supra note 16. 
dent professional judgment and render candid advice" neither empowers nor requires lawyers to act unilaterally. ${ }^{65}$ It requires them to be independent and candid when recommending courses of action. The members of the Working Group reached the conclusion they did because they "confused freedom of judgment with freedom of action. Lawyers must always have the former, but they rarely, if ever, have the latter and no rule requires clients to give it to them."66 As I wrote years ago when the battle over insurance defense lawyers' responsibilities was raging:

It is easy to forget, but essential to remember, that lawyers are first and foremost agents and advisors, not decision makers. Their job is to generate and recommend strategies for protecting clients' interests and, after doing so, to follow their client[s'] lawful marching orders as given. Following orders may require a lawyer to employ a strategy a lawyer neither recommends nor endorses. This does not mean that a client violates a duty to the lawyer or that a client impairs a lawyer's independence of professional judgment. As a principal, a client can properly decline to follow a lawyer's suggestions, including suggestions that are simply too expensive. No rule requires a client to pay a lawyer for actions a lawyer wants to take. That clients frequently reject expensive suggestions and require lawyers to stick to budgets is a matter to which any experienced lawyer will attest. ${ }^{67}$

A decision to reject a lawyer's recommendation cannot interfere with a lawyer's professional judgment. This is true whether the decision is made by a client, an insurer, or a third-party funder and regardless of the grounds upon which it is based.

Second, the Working Group erred when it contended that a contractual provision "permit[ting] the supplier to refuse further funding if the lawyer makes decisions in the course of the representation with which the supplier has a fundamental disagreement" can endanger a lawyer's ability to provide competent representation. ${ }^{68}$ To see why, suppose a lawyer recommends a litigation move that a client rejects. Can the lawyer be liable to the client for malpractice? No. It is black letter law that a client has no claim against a lawyer in this situation. The law treats the representation as competent because the lawyer made the recommendation, even though the client chose a different course.

It is reasonable to suppose that the law would treat the example described by the Working Group similarly. Suppose a lawyer recom-

65. Model Rules of Prof'l Conduct R. 2.1 (2013).

66. Silver, supra note 16, at 230-31 (footnote omitted).

67. Id. at 231 (footnotes omitted).

68. ABA White PAper, supra note 19, at 23. 
mends a course of action that a funder opposes. If the contract with the client empowers the funder to reject the recommendation, then the funder has stepped into the client's shoes and should be treated similarly. In practical effect, the client has retained the funder to manage the delivery of legal services, making attribution of the funder's decision to the client the sensible course. Alternatively, the funder may not control the decision but may threaten to withdraw support from the case. In this event, the client must decide whether to do as the lawyer recommends or as the funder wants, so responsibility for the outcome rests with the client yet again. That the client may feel pressure from the funder to follow a particular course should have no bearing on the result. Clients reject lawyers' recommendations for all sorts of reasons, including expense, and must often make unpleasant tradeoffs when doing so.

Third, the example used by the Working Group, which rests on the possibility that the funder will withdraw further financial support if the client pursues a particular course, has an analogue in insured litigation. An insurer can lawfully withdraw a paid defense in certain situations. The right to do so may arise, for example, when a policyholder refuses to cooperate in the defense, insists on controlling the defense, or exhausts the policy limits. Clearly, the possibility of losing a paid defense could be as serious a problem for a defendant as the loss of a funder's support might be for a plaintiff, and could easily influence either party's decisions. But the possibility that an insurer might decline to pay for the defense going forward has never been thought to justify a prohibition on insured representations or to raise insuperable problems for attorneys.

\section{Control of the Decision to Settle}

The Working Group worried a good deal about the possibility that a client might give a third-party funder control of the settlement decision, whether the grant of control would be revocable, and whether an irrevocable grant would require a lawyer to withdraw. After noting that clients can give lawyers revocable authority to settle, the Working Group continued:

In principle there would appear to be no reason why the client could not delegate revocable settlement authority to other agents. ... The more difficult question is whether a user of [thirdparty] financing may contractually agree to make an irrevocable authorization to the [funding] supplier to approve or reject a settlement offer. ... [A]s a matter of contract law a client may be able to enter into an enforceable provision in a contract with an ALF supplier, giving the supplier the right to accept or reject a proposed 
settlement. It is a significant open question whether that contractual delegation is such a significant limitation on the lawyer's representation of the client-because it interferes with the lawyer's exercise of independent professional judgment-that the lawyer must withdraw from the representation of a client who has agreed to such a contract provision. ${ }^{69}$

Once again, the prospect of limiting a lawyer's independent professional judgment reared its head.

When one focuses on the essentials, it is not clear why an irrevocable transfer of control of the settlement decision would pose any difficulty for an attorney. Suppose that after receiving a settlement offer a lawyer advises a client to accept it, believing, correctly one may suppose, that the client is likely to recover less at trial. In response, the client points out that the third-party litigation funder is entitled to make the call. The lawyer then gives the funder the same recommendation, which the funder either accepts or rejects. In either event, the lawyer is in the clear. By advising the client, and later the funder, to settle, the lawyer made the independent recommendation required by the disciplinary rules.

The client and the funder may disagree, of course. The client may want to accept an offer that the funder prefers to reject, or vice versa. Either situation may create difficulties for the plaintiff's attorney, but the proper path for the lawyer is reasonably clear. If the plaintiff and the funder are co-clients, the lawyer is prohibited from acting to the detriment of either and may not accept the settlement offer at the request of one over the objection of the other. If the funder is a nonclient payer, the lawyer must do what the plaintiff wants or, if the lawyer fears incurring civil liability to the funder, withdraw. ${ }^{70}$

The classic case of Rogers v. Robson, Masters, Ryan, Brumund \& Belom ${ }^{71}$ offers a relevant example from the insurance defense context. After being sued for medical malpractice, Dr. Rogers told the defense lawyers chosen by his insurer that he strongly opposed settling the case. $^{72}$ His professional liability policy entitled his insurer to settle without his consent, however, and the insurer instructed the lawyers to settle the lawsuit, which they did. Dr. Rogers then sued both the

69. ABA White PAPER, supra note 19 , at 26-27.

70. Under agency law, a lawyer may not ignore a client's instruction. Silver \& Syverud, supra note 33 , at $322 \&$ n.170. This is true even if the client promised not to give the instruction at issue, that is, even when the instruction is unauthorized. If the plaintiff made an irrevocable transfer of authority to the funder, a different issue may arise-namely, the possibility that the lawyer may incur liability to the funder by following the plaintiff's instruction. In this event, the safe course for the lawyer is to withdraw.

71. Rogers v. Robson, Masters, Ryan, Brumund \& Belom, 407 N.E.2d 47 (Ill. 1980).

72. Id. at 203-04. 
insurer and the defense lawyers for ignoring his demand. The former escaped liability on contractual grounds. ${ }^{73}$ Because the insurer was entitled to settle without Dr. Rogers's permission, the court found that he had no claim. The lawyers were not as lucky. Because they participated in an attorney-client relationship with Dr. Rogers, they were no freer to ignore his instruction than any other lawyer would have been. ${ }^{74}$ Agency law, not the insurance contract, governed the attorney-client relationship, and agency law imposes a duty of obedience. Instead of helping the carrier resolve the claim, the defense lawyers should have told it to exercise its power to settle by means of a claims representative or other agent who represented the carrier alone.

A third-party litigation funder would occupy the same position as the malpractice carrier in Rogers. Once empowered to accept a settlement offer without a plaintiff's consent, a funder would be free to do so directly or by means of an independent agent. It could also use the plaintiff's attorney to consummate the deal if the plaintiff was likeminded. Otherwise, a plaintiff's attorney would violate the duty of obedience by settling at the funder's request over the plaintiff's objection.

One can even imagine that third-party funders will take over responsibility for negotiating settlements entirely, leaving plaintiffs' attorneys out of the loop. Insurance companies regularly use claims professionals instead of defense lawyers when negotiating settlements. Why should similar arrangements not be available on the plaintiffs' side? Although plaintiffs' attorneys are accustomed to negotiating settlements, the scope of their representation of clients is not cast in stone. Their job could be limited to prosecuting claims, just as insurers often retain lawyers only to provide defense-related services.

The prospect of being excluded from settlement negotiations will likely rankle plaintiffs' attorneys, for whom handling negotiations has always been part of the job and one of its highlights. Exclusion may also cause financial concerns. When third-party funders handle negotiations, might they not also receive settlement checks? And if they do, what guarantee will plaintiffs' attorneys have of being paid and having their costs reimbursed? Will funders review attorneys' expenses before paying them? Will they provide settlement statements to plaintiffs, another task plaintiffs' attorneys have long performed?

73. Id. at $204-05$.

74. Id. at $205-06$. 
When one focuses on practical matters like these, one begins to see that the rise of third-party funding may radically alter the traditional plaintiffs' attorney's business model. As funders assume greater responsibility for costs, their control of claim prosecutions should grow. Eventually, they may dominate the process, as liability insurers do on the defense side. Lawyers who now practice independently and charge contingent fees may eventually become salaried employees of funders' staff counsel operations. Such far-reaching changes could be good for claimants. Competition for business should pressure funders to offer the best possible terms to claimants and to develop the most efficient working arrangements, including arrangements that minimize litigation costs.

\section{Settlement Incentives And Recommendations}

At present, of course, plaintiffs' attorneys continue to handle settlement negotiations and to make settlement recommendations to clients. Perhaps the most interesting difficulty stemming from thirdparty funding arrangements concerns the latter. How, if at all, should the fact that a client will share a recovery with a third-party funder affect a plaintiff's lawyer's settlement advice?

The Working Group struggled with this difficulty. Using an example discussed in Rancman v. Interim Settlement Funding Corp. ${ }^{75}$ the Working Group explained how dividing a recovery could affect a plaintiff's assessment of the desirability of a settlement:

[I]n the Rancman case, the Ohio Supreme Court was worried about the effect on settlement of the [funding] supplier's right to receive the first $\$ 16,800$ of settlement proceeds, in exchange for having previously provided the plaintiff with $\$ 6,000$. The court noted that, assuming the plaintiff was also obligated to pay her attorney a $30 \%$ contingency fee, she would be indifferent between a settlement offer of $\$ 24,000$ and nothing at all, because if she received nothing she would be permitted to keep the $\$ 6,000$ advanced by the supplier. ${ }^{76}$

75. Rancman v. Interim Settlement Funding Corp., 789 N.E.2d 217 (Ohio 2003).

76. ABA White PAper, supra note 19, at 27 (footnote omitted). Similar problems have arisen in other cases. For example, in Weaver, Bennett \& Bland, P.A. v. Speedy Bucks, Inc., the plaintiff figured out that she would make money only if the recovery exceeded $\$ 1.2$ million and therefore refused a settlement offer of $\$ 1$ million. 162 F. Supp. $2 d 448,451$ (W.D.N.C. 2001). In still other cases, clients who did not understand that little would be left over for them sued their lawyers for failing to protect their interests. One such instance is reported in Christine Simmons, Client Sues Firm After Funders Recover Most of His Settlement, N.Y. L.J., July 19, 2012, at 1. Not all of these suits have fared well. In Francis v. Mirman, Markovits \& Landau P.C., No. 029993/ 2010 (N.Y. Sup. Ct. Kings Cnty. Dec. 3, 2012), the trial court dismissed a malpractice complaint filed by a personal injury client who claimed that his lawyers failed to warn him that funders would receive nearly all of his recovery. Francis is discussed in Law Firm Wins Dismissal of Suit by Client Whose Litigation Loans Ate Up Settlement, 29 Laws. Man. on Prof. Conduct (ABA/ 
This analysis is correct. When deciding how to respond to settlement offers, the plaintiff would have ignored the $\$ 6,000$ advanced by the funding supplier, which was a sunk gain. ${ }^{77}$ As long as the odds of winning at trial were greater than $0 \%$, the plaintiff would have been better off trying the case.

The funding arrangement discussed in Rancman concerned the Working Group because it may have distorted the plaintiff's settlement-related incentives in a way that caused her to reject a valuemaximizing settlement opportunity. ${ }^{78}$ This is a real problem that can also arise in cases where subrogors stand to receive portions of plaintiffs' recoveries or where settlement payments are subject to thirdparty liens. ${ }^{79}$ When interests in recoveries (or liability exposures) are fractionated, the party controlling the settlement decision may find it personally advantageous to reject a reasonable settlement, even though this is not the jointly wealth-maximizing course. ${ }^{80}$ This is also a problem that funders and plaintiffs should be strongly motivated to address. They suffer when value-maximizing settlement opportunities are lost, so they should prefer working arrangements that enable them to avoid loss-inducing conflicts. ${ }^{81}$

BNA) 56 (Jan. 30, 2013). In another instance, a federal district court judge ruled that six women who were sexually assaulted while serving prison sentences in Michigan owed $\$ 3.1$ million of their $\$ 3.5$ million settlement to Money for Lawsuits, a funding company that advanced the women $\$ 635,000$ after they had won a $\$ 5.5$ million jury verdict. The verdict was later reduced to \$3.5 million. Kathleen Gray, Advance-Payment Firm Could Get Most of Abused Inmates' \$3.5Million Settlement from State, Detroit Free Press, Apr. 17, 2012, http://www.freep.com/article/ 20120417/NEWS06/204170389/.

77. The Rancman court may have meant to indicate that the plaintiff's calculation would have differed had she been required to reimburse the $\$ 6,000$ payment in the event of a loss at trial. That is correct, although to my knowledge, funders never require reimbursements. She would then have compared her portion of the $\$ 24,000$ settlement offer to her share of the expected recovery at trial, including the $\$ 6,000$ repayment obligation discounted by the estimated odds of losing the case.

78. ABA White PAPer, supra note 19, at 27 ("On the assumption that $\$ 24,000$ would otherwise be a reasonable settlement offer, the presence of ALF seems to have an adverse impact on the salutary goal of terminating litigation by settlement."). The Working Group also observed that a different funding contract, one that tied the funder's share to the duration of litigation, could make a plaintiff too eager to settle. See id. at 27-28.

79. For a cogent account of subrogation, see Sebok, supra note 60.

80. A similar problem has been discussed extensively in the insurance context, where policy limits fractionate exposure to liability risks. See Kent D. Syverud, The Duty to Settle, 76 VA. L. Rev. 1113 (1990); see also Charles Silver, A Missed Misalignment of Interests: A Comment on Syverud, The Duty to Settle, 77 VA. L. Rev. 1585 (1991).

81. Anthony Sebok informs me that funders attempt to avoid Rancman-like conflicts by limiting their investments to a small fraction of the estimated value of plaintiffs' claims. This increases the odds that plaintiffs will benefit by accepting reasonable settlement offers because they (plaintiffs) participate in the gains. 
But the Working Group did not believe that fractionated interests can create ethical problems for plaintiffs' attorneys. In its view, a plaintiff's decision to reject a settlement offer because her share of the payment is too small differs in no important respect from a plaintiff's decision to reject an offer for any other reason.

If, in the lawyer's judgment, the client would be better off rejecting a settlement offer and going to trial, then the lawyer should inform the client of this judgment .... One of the factors relevant to the client's decision might be the obligation to pay the fee charged by the [funding] supplier. Other factors unrelated to the merits of the lawsuit may be present as well, such as the client's risk tolerance, discount rate, need for funds, and preferences regarding a public trial. The presence of [litigation funding] is not different in kind from the other factors that are part of virtually any decision to settle; thus, they do not present distinctive ethical issues. ${ }^{82}$

It is certainly true that clients reject lawyers' settlement recommendations for all sorts of reasons, and the Working Group's assessment may well be right. That said, there is nonetheless a problem worth examining.

In none of the examples listed by the Working Group does a client reject a settlement offer while conceding that the offer is value-maximizing-i.e., that it is one that a person who owned $100 \%$ of the interest in a claim would rationally accept. Consequently, in all of the examples, a plaintiffs' attorney's responsibility is consistent with the lawyer's desire to maximize the contingent fee. Consider clients who are risk-averse. They are inclined to accept offers that are inadequate, as are clients with high discount rates, urgent needs for funds, or strong aversions to trial. A plaintiffs' attorney's job when dealing with these clients is to convince them to hold out for more money. This task is compatible with the lawyer's fee arrangement, which rewards the lawyer for maximizing the value of the claim. Now consider riskpreferring clients. They will reject value-maximizing offers because they find them insufficient. Clients with low discount rates, little need for money, or strong preferences for trials also want or think they deserve more than has been offered. When dealing with one of these clients, a plaintiff's attorney must convince the client to be reasonable. Again, this assignment is compatible with the lawyer's fee arrangement because reasonable action by the plaintiff will benefit the attorney.

Fractionated interests create a different problem. As mentioned, they can motivate plaintiffs to reject reasonable offers while conced-

82. ABA White PAPer, supra note 19, at 28. 
ing that the offers maximize the value of their claims. In this situation, by doing anything other than convincing the client to accept the offer, a lawyer would reduce the expected fee. In other words, by honoring a funded client's wish to take a flyer when only by winning big at trial can the plaintiff pocket any money, a lawyer would have to expect to do worse than if the case settled on the terms being offered. If the lawyer's professional obligation is to do what is best for the client, then the obligation and the fee arrangement, which punishes the lawyer for trying the case, are at odds.

I find it hard to expect lawyers to fulfill their responsibilities in Rancman-like situations. Everything likely to influence their judgment is wrong. Having expended the time and borne the expenses needed to obtain value-maximizing settlement offers, the clients' decisions to go to trial will leave the lawyers angry and disappointed. The clients' desires will also saddle the lawyers with a risk of losing their sunk costs and the unwelcome prospect of expending even more resources with no reasonable expectation of a fee increase sufficient to warrant the gamble.

Many lawyers will foresee the problems I have described. The rest will appreciate them after enduring a Rancman-like experience once. One might therefore expect plaintiffs' lawyers to obtain additional assurances that their clients will accept value-maximizing settlement offers. To accomplish this, they may change the terms of their relationships with clients who receive third-party funding. Perhaps they will require these clients to pay higher fees after rejecting settlement recommendations. Or perhaps they will simply withdraw.

Of course, the matter is not all downside from plaintiffs' lawyers' point of view. They may be compensated in advance for bearing the conflicts third-party funding arrangements entail. To see why, suppose a lawyer handles ten funded cases, one of which generates a Rancman-like problem and nine of which garner increased settlements as a result of funders' participation, which enables the plaintiffs to hold out for better deals. In the nine successful cases, the lawyer earns larger fees. In the one Rancman-like case, the lawyer is exposed to a loss. Does the participation of third-party funders make the lawyer better off or worse off across all ten cases? The answer depends on facts that have not been set out, but if the lawyer agrees to handle funded cases, one can reasonably infer that, in the lawyer's view, the expected gain exceeds the expected cost.

Insofar as lawyers are concerned, then, litigation funding has plusses and minuses. The most important issue is probably whether lawyers are informed of third-party funders' participation up front, so 
they can intelligently decide whether to accept or reject requests for representation. One supposes that lawyers will recognize the need for this information and develop means to address it. It seems likely that funders will inform lawyers of their presence as well, if only to ensure that they are paid before funds are disbursed to plaintiffs.

Finally, it is worth noting that insurance law deals with a problem analogous to Rancman on the defense side by subjecting carriers to a duty to settle. Policy limits divide exposure to losses between carriers and insureds. Consequently, insurers can have incentives to reject reasonable settlement demands at or within the limits. After receiving such a demand, an insurer may figure that it cannot lose much more at trial (because the policy limits cap its exposure), but it will save a lot if the jury finds in the defendant's favor. The rational course may therefore be to reject the settlement demand and take a flyer at trial. The duty to settle arose to motivate carriers to focus on the total trial exposure, rather than just the portion they bear, when making settlement decisions. ${ }^{83}$

One can imagine a similar duty arising on the plaintiff side in cases involving third-party funders. After rejecting a settlement offer unreasonably and losing at trial, a court would require the person who made the decision to hold the other, and possibly the plaintiff's attorney, harmless. Because only funders would have enough money to make good on this responsibility, one might expect control to gravitate in their direction. A properly designed penalty would then encourage decisions based on expected trial recoveries, rather than fractional shares of settlement payments.

A "hammer clause" is another possibility. When a liability policy contains a "consent to settle clause" that entitles a policyholder to veto a settlement an insurer wants to accept, the insurer faces a risk of incurring additional defense costs and a larger judgment-related loss at trial. In effect, a consent to settle clause enables a policyholder to protect its own interests by saddling its insurer with greater risks. Not wanting its policyholder to be able to spend its money, an insurer will therefore pair a consent to settle clause with a hammer clause that puts the policyholder on the hook for post-rejection losses. ${ }^{84}$ "The

83. On the duty to settle, see Syverud, supra note 80.

84. A typical hammer clause might read as follows:

We will not settle any claim or "suit" without the first Named Insured's consent. However, if the first Named Insured refuses to consent to the settlement of such claims or "suit" after first receiving our request for consent to settle, and the first Named Insured elects to contest such claim or "suit" and continues legal proceedings for such claim or "suit," then our liability to pay damages under this policy will be the lesser of the following: 
hammer clause has severe consequences for the insured," including responsibility for post-rejection defense costs, prejudgment interest, and any payment to the claimant that exceeds the settlement demand. ${ }^{85}$ With a hammer clause in place, a policyholder will veto a carrier's request to settle only when it "feel[s] very strongly about the merits of the case, or about the message it sends to claimants." 86

By rejecting a settlement offer that a third-party funder wants to accept, a plaintiff would force a funder to incur additional risks. An optimal funding contract would therefore encourage a plaintiff to reject only offers that are not value-maximizing. In theory, a hammer clause could have this effect by forcing a plaintiff who rejects an offer wrongly to bear the cost of the mistake. A suitable clause will be difficult to design, however. Only plaintiffs in commercial cases will have enough money to indemnify third-party funders against post-rejection losses. Personal injury plaintiffs might be required to remit part of their advances or to pay their funders additional compensation, but both remedies will work imperfectly. Many personal injury plaintiffs will spend their advances shortly after receiving them. Payment penalties will also have little or no impact on plaintiffs in Rancman-like situations. After rejecting settlement offers, they will be insolvent when they lose at trial (and, therefore, unable to pay penalties) and when they win big, they will still be better off (because they will keep part of the gain).

\section{Confusion And Conflicts}

In the section of its report addressing the independent judgment requirement, the Working Group also included a paragraph expres-

- up to and not to exceed the amount of damages set forth in our request to settle; or

- the limits of insurance (as set forth in $\S 19.7 .1$, Termination of the Duty to Defend). Additionally, all further legal expenses, costs, and supplementary payments incurred by an insured after the date of such refusal of the consent to settle will be the responsibility of such insured.

Joyce F. Frank \& Lauren F. Goldberg, Insurance Coverage for Municipalities, in MAssachuSetts Municipal Law § 19.4.9 (2d Supp. 2012); see also James D. Cox, The Social Meaning of Shareholder Suits, 65 BRook. L. Rev. 3, 32 (1999) (discussing the use of hammer clauses in D\&O insurance).

85. Frank \& Goldberg, supra note $84, \S 19.4 .9$.

86. Id. D\&O insurance policies, which give policyholders considerable control over settlement, address the mirror-image problem that insureds may want to spend insurers' money too freely by entitling carriers to veto settlements recommended by policyholders. See Baker \& Swedloff, supra note 32, at 1426 ("The D\&O policy also gives insureds significant control over the settlement process, subject to the obligation to obtain the insurer's consent. As a result, the insurer's only protections against ex post moral hazard are the right to refuse to reimburse unreasonable defense costs and the right to refuse to consent to an unreasonable settlement."). 
sing a series of conflict-related concerns stemming from confusion over matters relating to the control of litigation:

Situations can be foreseen (and perhaps some cannot) in which the interests of the [funding] supplier conflict[] with what the lawyer perceives to be in the best interest of the client. The existence of the financing arrangement may sow confusion about who actually owns the claim, who controls the lawsuit, the role (if any) of the [funding] supplier participating in significant decision-making during the litigation, and how to resolve conflicts between the client's directive, the [funding] supplier's financial expectations, and the lawyer's assessment of the client's best interests. ${ }^{87}$

It is certainly plausible that conflicts like these will arise. Differences regarding settlement decisions seem especially likely, if recent cases provide a reliable guide. In one instance, a client rejected her lawyers' recommendation to accept a settlement because a litigation funder would have received all the money. After the case was tried and lost, the lawyers, who did not know about the funding relationship, sued the funder for tortious interference with the attorney-client relationship. ${ }^{88}$ More generally, the possibility of conflicts between or among plaintiffs, funders, and plaintiffs' attorneys must be admitted freely.

While recognizing the potential for conflicts, one can nonetheless wonder how often they will arise and how severe they will be. On the insurance side, interest conflicts have not proven to be so serious as to warrant a prohibition on the sale of coverage or the joint representation of policyholders and carriers. Conflicts arising in funded cases may also prove to be manageable, especially over the longer haul. After conflicts arise in the first wave of funded cases, more efficient working arrangements are likely to evolve.

Of course, efficient contract provisions may leave a good deal unsaid. Consider liability contracts, billions of which are likely in force at any given time. The standard defense clause, a core policy provision, is simple. It says that the insurer has the right and duty to defend lawsuits seeking covered damages. The standard settlement clause is also brief. It merely gives the carrier discretion to settle claims. Other

87. ABA Comm'n on Ethics 20/20, White Paper on Alternative Litigation Financing 26 (Oct. 19, 2011), available at http://www.americanbar.org/content/dam/aba/administrative/ethics_2020/ 20111019_draft_alf_white_paper_posting.authcheckdam.pdf (earlier draft of ABA WHITE PAPER, supra note 19).

88. Weaver, Bennett \& Bland, P.A. v. Speedy Bucks, Inc., 162 F. Supp. 2d 448, 450-51 (W.D.N.C. 2001); see also Gary Young, No Advance to the Rear: Litigation Financiers Have Been Hurt by Ohio, North Carolina Rulings, but the Industry Shows No Sign of Disappearing, 78 Miami Daily Bus. Rev. 8, 10 (2003); cf. Stephen Gillers, Regulation of Lawyers: Problems of Law \& Ethics 146 (9th ed. 2012) (presenting examples of settlement-related conflicts connected to contingent percentage fees). 
provisions, such as the cooperation clause, are more detailed but are also vague in important respects, such as whether a failure to cooperate must prejudice a carrier before coverage can be withdrawn. All three provisions (and many others found in insurance contracts) have spawned uncertainty and litigation, but no one sees this as a reason to prohibit insurers from selling coverage or to prevent defense lawyers paid by insurers from representing policyholders.

A learning process should also occur as a result of litigation. With third-party funding in its infancy, disagreements and planning failures are to be expected. The resulting disputes will slowly produce a body of caselaw governing the enforceability and interpretation of funding contracts. Funders, plaintiffs, and lawyers will then adjust their working arrangements, expectations, and understandings in light of the information courts produce, and the frequency of disagreements should decline. ${ }^{89}$

\section{Too Much Litigation}

A host of objections to third-party litigation funding contend that enhancing plaintiffs' access to capital will encourage litigation, with deleterious consequences. ${ }^{90}$ The U.S. Chamber of Commerce espouses this view. It contends that third-party funding will enable lawyers to file more frivolous cases and abusive class actions, prolong lawsuits, and permit funders to instigate lawsuits that, but for their prompting, would not be waged. ${ }^{91}$ Paul Rubin contends that thirdparty funders, as repeat players with long-term interests in litigation, will support expansive readings of tort law doctrines that will burden society with costs not justified by the benefits they generate. ${ }^{92}$

Objections like these are empirical, and rigorous empirical study of the impact of third-party funding is an infant industry. Consequently, nothing conclusive can be said at this time. It is not even clear that the theories said to support the allegations actually warrant them.

Consider the study by David Abrams and Daniel Chen that the U.S. Chamber of Commerce cited to support its claim that third-party

89. This is the standard economic view of the information-producing function of courts. See Charles Silver, Do We Know Enough About Legal Norms?, in Social Rules: Origin; CharacTER; Logic; Change 141 (David Braybrooke ed., 1996).

90. See, e.g., Paul H. Rubin, Third-Party Financing of Litigation, 38 N. Ky. L. Rev. 673, 677 (2011) ("[T]he obvious effect of increased third party financing would be increased litigation, where litigation refers to both the filing of cases and litigation of cases rather than settling.").

91. U.S. Chamber Inst. For Legal Reform, supra note 61, at 10-14, 16-21.

92. Rubin, supra note 90 , at 682-85. 
funding will encourage litigation. ${ }^{93}$ The first noteworthy aspect of the study is that Abrams and Chen start from the premise that litigation is undersupplied because tort victims cannot sell their claims. The Chamber, a partisan political group, does not mention the possibility that enhanced access to funding may correct a shortage of litigation. Second, when discussing the economics of litigation, Abrams and Chen observe that third-party funding may not cause "an overall increase in litigation." 94 To the contrary, settlement rates may "increase . . . as defendants adapt[] to the involvement of third-party funders." 95 Abrams and Chen further undermine the Chamber's position by noting, third, that funders prefer strong cases to weak ones. Relying on other research, they noted that one funder would only invest in cases with a $95 \%$ probability of winning, while another required a $50 \%$ chance. Overall, funders "prefer[red] cases that [were] likely to settle quickly, because the longer and more complex a matter is, the greater [their] risk." 96 Fourth, in a possible riposte to Rubin, they point out that "an additional benefit of litigation trading may be clarification of the law. . . [P]reviously unaddressed legal questions would arise and be resolved more quickly[,] . . . lead[ing] to more efficient behaviors as parties make better-informed decisions." 97 One might add that the questions should be serious ones, given the willingness of third-party funders to expend the resources needed to raise them.

Finally, and as the Chamber reported, Abrams and Chen's empirical analysis of litigation in Australia found "a pattern of increased funding corresponding to slower case processing, larger backlogs, and increased spending by the courts." 98 But in their concluding remarks, the authors were careful to limit the inferences that may properly be drawn from this:

While congesting the courts may be a cost of third-party funding, the overall welfare effects could still be positive. If the value of the adjudication of cases is greater than the expense of adjudicating them, then third party [sic] funding should be encouraged. Further, court congestion may be a transitory effect of the entry of litigation funders, and not one that persists. The expectation would be that once defendants recognize the increased likelihood of litigation and

93. David S. Abrams \& Daniel L. Chen, A Market for Justice: A First Empirical Look at Third Party Litigation Funding, 15 U. PA. J. Bus. L. 1075 (2013). In its publication on third-party financing, the Chamber of Commerce cited an earlier unpublished draft of this study from 2009. 94. Id. at 1079 .

95. Id. at $1079-80$.

96. Id. at 1088 .

97. Id. at 1080 .

98. Id. at 1103 . 
the greater resources held by plaintiffs, they would be more likely to settle in equilibrium. While transitioning to that new equilibrium, there is another potential benefit from litigation funding: earlier resolution of the law. ${ }^{99}$

Thus, although the Chamber concluded that third-party funding should be prohibited, Abrams and Chen did not.

Although Abrams and Chen are the only researchers to have studied the impact of third-party funding empirically, ${ }^{100}$ others have developed economic models of parties' incentives. Their predictions often differ, sometimes radically, from the Chamber's dismal view. For example, Andrew Daughety and Jennifer Reinganum argue that optimally sized nonrecourse loans will induce all cases to settle, as long as funders refrain from controlling litigation. ${ }^{101}$ Roland Kirstein and Neil Rickman model litigation with and without third-party contracts, which may be entered into before or after settlement negotiations start. ${ }^{102}$ They predict that, when the plaintiff and the funder contract at the outset, settlement with the defendant is expected and will occur on more favorable terms than the plaintiff would receive without the funder's assistance. The plaintiff and the funder divide the expected gain in settlement value, with the latter's share representing the premium for the insurance provided against the risk of loss.

By focusing on litigation rates in courts, the U.S. Chamber of Commerce also ignores the possible impact the availability of funding may have on primary conduct, which may be greater and more important than its effects on lawsuits. The easier access to justice becomes, the greater the incentive potential wrongdoers should have to avoid imposing losses on others. In other words, the likelihood of enforcement should affect the rate at which people and businesses commit torts, breach contracts, or act in other wrongful ways. By enabling people to assert claims who would otherwise sit on their hands, and by enabling claimants to hold out for payments that more closely approximate the judgments they would receive at trial, third-party litigation funding may create incentives that cause both the frequency of claims and the rate of litigation to decline. As Steven Garber observes,

99. Abrams \& Chen, supra note 93 , at $1106-07$.

100. For a summary of empirical studies of fee arrangements, including contingent fees in the United States, see Paul Fenn \& Neil Rickman, The Empirical Analysis of Litigation Funding, in New Trends in Financing Civil Litigation in Europe: A Legal, Empirical, and EcoNOMic Analysis 131 (Mark Tuil \& Louis Visscher eds., 2010).

101. Andrew F. Daughety \& Jennifer F. Reinganum, The Effect of Third-Party Funding of Plaintiffs on Settlement (Vanderbilt Univ. Law Sch., Law \& Econ. Working Paper No. 13-8, 2013), available at http://ssrn.com/abstract=2197526.

102. Roland Kirstein \& Neil Rickman, "Third Party Contingency" Contracts in Settlement and Litigation, 160 J. Institutional \& Theoretical Econ. 555 (2004). 
[I]f [alternative litigation funding] enables many individuals or organizations to strengthen their claims or to bring claims that they otherwise would not bring, this could increase the costs to potential defendants of activities that lead to claims and, as a result, decrease behavior that causes or allegedly causes compensable harms. Stated simply, if [alternative litigation funding] increases deterrence of behavior that tends to lead to lawsuits, this effect will tend to reduce, not increase, the volume of litigation. ${ }^{103}$

By focusing on litigation and diverting attention away from primary behaviors that take place outside of courts, the Chamber may cause readers to miss the forest for the trees. ${ }^{104}$

One really would like to appreciate the impact third-party funding has on aggregate social welfare. In theory, comparative studies could shed light on its desirability overall, but the subject has not been studied quantitatively yet and years will likely pass before it is. That said, empirical studies do tend to show that countries with honest civil justice systems that permit private enforcement of legal rights tend to do better than others economically. Although access to justice imposes significant costs on everyone involved, its benefits appear to be even greater. ${ }^{105}$

\section{Conclusion}

Liability insurance is a fixture of civil litigation in the United States. But it was once a new arrival. According to the late Professor Gary Schwartz, "Tort liability insurance seems not to have existed in this country prior to 1886." $106 \mathrm{He}$ added that, when "companies began offering negligence insurance policies," the legality of contracts that insulated wrongdoers from the consequences of torts was controversial.

A short series of judicial opinions proceeded to address the question of whether the common law should give effect to these insurance contracts. The finale of this series-the Missouri Supreme Court's divided opinion in Breeden v. Frankford Marine Plate Accident \& Glass Insurance Company [sic]—now serves as a standard

103. GARBER, supra note 8 , at 29 .

104. The history of the anesthesia patient safety movement bears out the suggestion that claiming can drive improvements that lower error rates. See David A. Hyman \& Charles Silver, The Poor State of Health Care Quality in the U.S.: Is Malpractice Liability Part of the Problem or Part of the Solution?, 90 Cornell L. Rev. 893, 922 (2005).

105. Third-party funding may also have the potential to improve the quality of justice, if courts would allow parties to admit funding agreements into evidence. See Ronen Avraham \& Abraham L. Wickelgren, Admissible Third Party Litigation Funding Contracts as a Way To Constrain the Exploitation of Plaintiffs 3 (Univ. of Tex. Sch. of Law, Law \& Econ. Research Paper No. 242, 2011), available at http://ssrn.com/abstract=1986951.

106. Schwartz, supra note 3, at 314. 
citation for the conclusion that negligence liability insurance policies are legally proper. ${ }^{107}$

The legality of shifting the financial responsibility for torts to liability carriers is now clear, even though some practices, such as insuring against punitive damages, remain controversial. ${ }^{108}$

Third-party litigation funding is the new kid on the block, and its potential to disturb existing litigation arrangements is clear. It may change litigation control arrangements on the plaintiffs' side and force plaintiffs' attorneys to change their business models. It may create new interest conflicts that attorneys will have to identify and deal with. It may end the "good times" for liability insurers by forcing them to compensate injured claimants more fully than they used to. It may vitalize claims that formerly would have been dormant, saddling wrongdoers with additional costs and forcing them to show greater concern for others' legal rights.

Given the changes third-party funding may impel, the controversy surrounding it is predictable. Innovations that affect important working arrangements produce winners and losers, and the likely losers routinely use whatever means, public and private, are available to insulate themselves. Plaintiffs' attorneys seek ethics opinions from state bar associations and the ABA. Insurers and other repeat players on the defense side pay think tanks, trade associations, and lobbyists to attend legislative hearings, publish op-eds, and produce reports warning that the sky will fall. And everyone uses the courts, especially when innovations affect the delivery of legal services and the conduct of civil litigation-matters over which judges claim extensive authority and special expertise.

Such campaigns sometimes stop innovations in their tracks, ${ }^{109}$ but one suspects that third-party litigation funding is here to stay. The basic driver in the consumer litigation sector is that injured claimants need the money third-party funders provide. One suspects that judges and other policy makers, recognizing the legitimacy of victims' desires, will leave open channels for them to get the support they need. In the commercial litigation sector, there is cause for optimism because busi-

107. Id. (footnote omitted) (citing Breeden v. Frankfort Marine, Accident \& Plate Glass Ins. Co., 119 S.W. 576 (Mo. 1909)).

108. See, e.g., Janet R. Davis \& Gary L. Gassman, The Ins and Outs of Employment Practices Liability Insurance Coverage and Claims, BRIEF, Winter 2013, at 22, 29 ("Policies now often include coverage for punitive damages, which may be awarded under discrimination statutes. However, the availability of coverage generally is still subject to a jurisdiction's public policy regarding the insurability of punitive damages.").

109. See Silver, supra note 64 , at 820-23 (discussing the successful campaign by defense lawyers to prevent liability insurers from using third-party fee auditors). 
nesses will be divided and because the law tends to let sophisticated parties contract as they please. Any business could find itself short on funds or reluctant to bear all the risks of litigation when acting as a plaintiff. Consequently, businesses may not want to cut off access to third-party funders entirely. And intelligent regulators should see no greater need to protect businesses from third-party funders than from banks, investors, or other sources of capital. 
